\title{
Reprogramming the Constant Region of Immunoglobulin G Subclasses for Enhanced Therapeutic Potency against Cancer
}

\author{
Tae Hyun Kang ${ }^{1}$ and Sang Taek Jung ${ }^{2, *(1)}$ \\ 1 Biopharmaceutical Chemistry Major, School of Applied Chemistry, Kookmin University, Seoul 02707, Korea; \\ thkang@kookmin.ac.kr \\ 2 Department of Biomedical Sciences, Graduate School of Medicine, Korea University, Seoul 02841, Korea \\ * Correspondence: sjung@korea.ac.kr; Tel.: +82-2-2286-1422
}

Received: 26 December 2019; Accepted: 24 February 2020; Published: 1 March 2020

\begin{abstract}
The constant region of immunoglobulin (Ig) G antibodies is responsible for their effector immune mechanism and prolongs serum half-life, while the fragment variable (Fv) region is responsible for cellular or tissue targeting. Therefore, antibody engineering for cancer therapeutics focuses on both functional efficacy of the constant region and tissue- or cell-specificity of the Fv region. In the functional aspect of therapeutic purposes, antibody engineers in both academia and industry have capitalized on the constant region of different $\operatorname{IgG}$ subclasses and engineered the constant region to enhance therapeutic efficacy against cancer, leading to a number of successes for cancer patients in clinical settings. In this article, we review IgG subclasses for cancer therapeutics, including (i) IgG1, (ii) IgG2, 3, and 4, (iii) recent findings on Fc receptor functions, and (iv) future directions of reprogramming the constant region of IgG to maximize the efficacy of antibody drug molecules in cancer patients.
\end{abstract}

Keywords: immunoglobulin G; therapeutic antibodies; Fc receptors; cancer therapy

\section{Introduction}

Therapeutic monoclonal antibodies (mAbs) comprised more than $70 \%$ of global biologics revenue in 2018 [1]. Up to 21 January 2020, the US Food and Drug Administration (FDA) and European Medicines Agency (EMA) approved 74 therapeutic antibodies, 29 of which were for cancer-related disease (39\%) (Figure 1a). Interestingly, IgG1 constitutes at least 22 of the 29 cancer-related therapeutic antibodies, while all other IgG subclass antibodies, including IgG4 but not panitumumab (IgG2), were approved in 2014 or later (Figure 1b) [2]. As of January 2020, human or humanized antibodies constituted more than $70 \%$ of the total cancer-related antibodies (Figure 1c). Among the 29 antibodies, 8 were for blood cancer and the other 21 were for solid cancer treatment (Figure 1d), including breast cancer, colorectal cancer, head and neck cancer, lung cancer, rectal cancer, glioblastoma, melanoma, myeloma, neuroblastoma, and sarcoma [2,3]. 
(a) Disease Indications

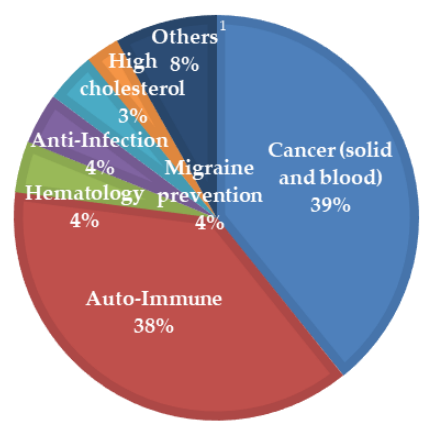

(c) Antibody Species type

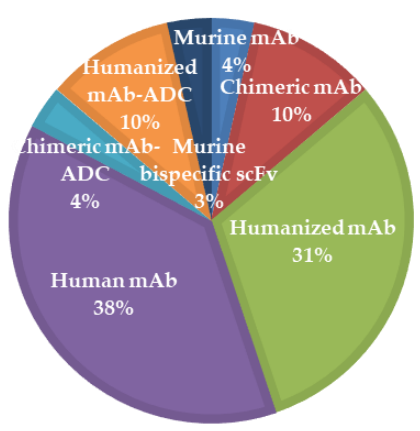

(b) IgG Subclasses

- Cancer (solid and blood)

- Auto-Immune

Hematology

- Anti-Infection

Migraine prevention

- High cholesterol

- Others $^{1}$

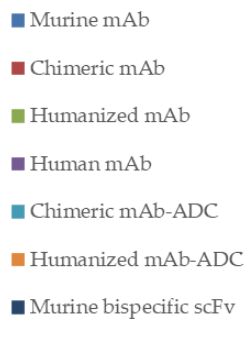

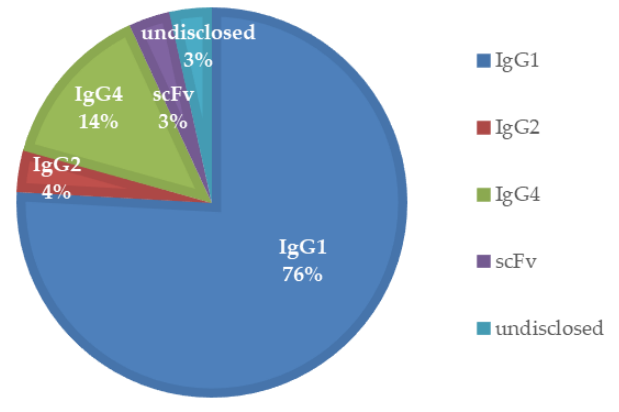

(d) Cancer Types

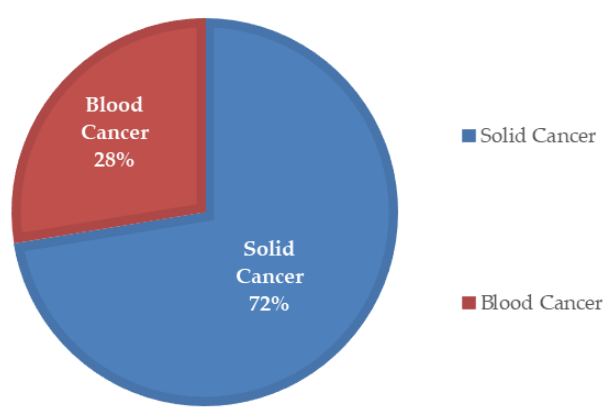

Figure 1. Indication and molecular types of therapeutic antibodies approved by the US FDA and EMA, classified by (a) disease indications of all 74 therapeutic antibodies; (b) antibody subclasses of 29 antibodies for cancer; (c) species type of 29 antibodies for cancer, i.e., murine, chimeric, humanized, or fully human; and (d) cancer types of 29 antibodies for cancer (blood or solid cancer). These figures were classified using data from "The Antibody Society (2020)" [2]. ${ }^{1}$ Others in panel (a) include prevention of kidney transplant, macular degeneration, Muckle-Wells syndrome, bone loss, high cholesterol, $\mathrm{X}$-linked hypophosphatemia, and osteoporosis in postmenopausal women at increased risk of fracture.

It is undeniable that antibody therapies have greatly improved the survival rate of cancer patients, and they are considered one of the most effective disease-targeting moieties for cancer. This is because therapeutic antibodies selectively target cancerous cells or immune leukocytes and thus exhibit lower toxicity compared to conventional small molecule-based chemotherapy or radiotherapy. However, treatments with mAbs rarely lead to complete recovery from diseases [4]. Therefore, $\mathrm{mAbs}$ require combination with other toxic therapeutic modalities [5-7], despite their extraordinary specificities for cancer tissue or immune leukocytes. When they directly target tumor associated antigens (TAAs) [8-11], the native effector function of mAbs may not be sufficient to eradicate refractory tumor cells, and tumor cells may be resistant to immune effector cells when mAbs target and activate immune leukocytes [12-16]. This necessitates understanding of the antibody effector mechanism underlying Fc-Fc receptor biology and obliges antibody engineers to investigate the effector functions of $\mathrm{mAbs}$ with desired constant regions.

As of January 2020, all FDA- and EMA-approved immunoglobulin isotypes are IgG antibodies $[2,18]$. These antibodies bind to the family of Fc receptors (Fc gamma receptors, Fc $\gamma$ Rs) to activate or inhibit signaling that mediates complex immune responses upon formation of immune complexes $[19,20]$. The Fc $\gamma$ Rs bind IgGs [21-23] to initiate and regulate various effector functions, such as inhibition of B cell proliferation, phagocytosis, degranulation of cytotoxic molecules in granulocytes, and cytokine production [24,25]. Three different classes of human Fc gamma receptors for IgG have been identified: Fc $\gamma$ RI (CD64), Fc $\gamma$ RII (CD32), and Fc $\gamma$ RIII (CD16) [26]. Among Fc $\gamma$ Rs, Fc $\gamma$ RI exhibits high affinity $\left(\mathrm{K}_{\mathrm{D}}=10^{-8} \mathrm{M}\right)$ to the antibody-constant region, whereas Fc $\gamma$ RII and Fc $\gamma$ RIII display low affinity $\left(\mathrm{K}_{\mathrm{D}}=10^{-6} \sim 10^{-7} \mathrm{M}\right)$ to the fragment crystallizable $(\mathrm{Fc})$ region of IgG [27]. Mechanistically, 
Fc $\gamma$ Rs are grouped into two groups: activating Fc $\gamma$ Rs such as Fc $\gamma$ RI (CD64), Fc $\gamma$ RIIa (CD32a), and Fc $\gamma$ RIIIa (CD16a), and the inhibitory Fc $\gamma$ R, Fc $\gamma$ RIIb (CD32b). These activating and inhibitory Fc $\gamma$ R transduce their functional signaling through immunoreceptor tyrosine-based activation motif (ITAM) or inhibitory motif (ITIM), respectively [20,21].

Human Fc $\gamma$ RI (CD64) is a glycoprotein that binds to monomeric IgG with high affinity $\left(\mathrm{K}_{\mathrm{D}}=\right.$ $\left.10^{-8} \sim 10^{-9} \mathrm{M}\right)$. Human Fc $\gamma$ RI binds with high affinity to IgG1 and IgG3 but binds weakly to IgG4 and very weakly with IgG2 (Table 1) [28]. Fc $\gamma$ RI consists of an $\alpha$-chain with multiple glycan chains and two $\gamma$-chain subunits of FceRI $[29,30]$.

Table 1. Molecular properties of IgG antibody subclasses.

\begin{tabular}{|c|c|c|c|c|c|c|c|c|c|}
\hline \multirow{2}{*}{$\begin{array}{c}\text { IgG } \\
\text { Subclasses }\end{array}$} & \multirow{2}{*}{$\begin{array}{l}\text { Hinge Length (Amino } \\
\text { Acid Residues) }\end{array}$} & \multirow{2}{*}{$\begin{array}{c}\text { Number of Disulfide } \\
\text { Bonds in the Hinge Region }\end{array}$} & \multirow{2}{*}{$\begin{array}{l}\text { Serum Half-Life } \\
\text { (Week) }\end{array}$} & \multicolumn{6}{|c|}{$\begin{array}{c}\text { Relative Affinities to Fc } \gamma \mathbf{R s}^{2} \\
\text { (Expected Effector Functions via Fc } \gamma \text { Rs) }\end{array}$} \\
\hline & & & & I & IIa & IIb & IIc & IIIa & IIIb \\
\hline IgG1 & 15 & 2 & 3 & +++ & +++ & + & + & ++ & +++ \\
\hline IgG2 & 12 & $4^{1}$ & 3 & - & ++ & - & - & $-1+$ & - \\
\hline IgG3 & $62^{1}$ & $11^{1}$ & 1 & ++++ & ++++ & ++ & ++ & ++++ & ++++ \\
\hline IgG4 & 12 & 2 & 3 & ++ & ++ & ++ & ++ & - & - \\
\hline
\end{tabular}

Fc $\gamma$ RII is expressed more frequently on cells of hematopoietic lineage compared to other Fc $\gamma$ Rs. There are three different Fc $\gamma$ RII isoforms: Fc $\gamma$ RIIa, Fc $\gamma$ RIIb, and Fc $\gamma$ RIIc. Whereas Fc $\gamma$ RIIa and Fc $\gamma$ RIIc transmit activating signals on immune leukocytes, Fc $\gamma$ RIIb produces inhibitory signals throughout the membranes of blood cells. Fc $\gamma$ RIIa exhibits diverse expression profiles on macrophages, monocytes, neutrophils, and platelets. Relative to Fc $\gamma$ RIIa, Fc $\gamma$ RIIc has been reported to be expressed less frequently, though it is uniquely present on natural killer (NK) cells [31]. Fc $\gamma$ RIIa is generally thought to be responsible for phagocytosis, cytotoxicity, and inflammatory cytokine release, but these mechanisms remain to be validated. Unlike Fc $\gamma$ RIIa, Fc $\gamma$ RIIb can be found on basophils, mast cells, monocytes, macrophages, dendritic cells (DC), and even B cells. Fc $\gamma$ RIIb down-regulates immune activating signals by flanking the triggered activating Fc $\gamma$ Rs [32].

There are two Fc $\gamma$ RIII isoforms identified so far: Fc $\gamma$ RIIIa and Fc $\gamma$ RIIIb. Fc $\gamma$ RIIIb is expressed on neutrophils, and activation of $F_{C} \gamma$ RIIIb stimulates degranulation and production of reactive oxygen intermediates (ROI) in neutrophils [33]. Fc $\gamma$ RIIIa is well-known for its contribution to ADCC activity because it is the only Fc $\gamma \mathrm{R}$ expressed on NK cells. It is also regarded as an initiator for endocytosis, phagocytosis, and cytokine production of existing immune leukocytes; however, the exact implications are still unknown. The downstream signal transduction triggered by Fc $\gamma$ RIIIa as well as Fc $\gamma$ RI requires association of $\gamma$ or $\zeta$ chain on the cell surface [34,35].

Fc $\gamma$ Rs are important in mediation of both humoral immunity and immunologic responses [36]. The functions of $F_{c}$ receptors must be elucidated to establish a direction for reprogramming the constant regions of IgG antibodies for therapeutic purposes. However, it is not possible to elucidate the function of Fc $\gamma$ Rs in various human leukocytes with irregular Fc $\gamma$ Rs profiles [37] without Fc $\gamma$ R-selective Fc.

Despite the negligence of Fc $\gamma$ Rs function, researchers in academia and biopharmaceuticals have extensively investigated constant regions of IgG subclasses and even engineered them to maximize therapeutic efficacy in cancer therapy. In this paper, we review advantages and disadvantages of IgG subclasses for therapeutic usage, including i) IgG1, ii) IgG2, 3, and 4, based on known molecular properties and affinities to Fc receptors, iii) recent findings on Fc receptor functions for antibody cancer therapy, and finally iv) future directions of reprogramming the constant region of the IgG antibody for better cancer therapy.

\section{IgG1: The Most Abundant IgG Antibody in Cancer Therapeutics}

IgG1 shows the highest serum abundance (65\% of total $\mathrm{IgG}$ ) [38] and is the most commonly used therapeutic IgG antibody among IgG subclasses [2] because of its (i) significant binding to Fc $\gamma$ Rs, (ii) short hinge length (15 amino acid residues) with two inter-heavy chain disulfide bonds, enabling 
relatively facile bioprocessing, and (iii) long serum half-life (Table 1). One immunosurveillance mechanism in cancer involves generation of IgG antibodies that surround tumor cells via affinities to cancer antigens. Especially, cancer-specific IgG1 antibodies attract diverse immune cells to the cancer site by Fc-Fc $\gamma$ Rs interactions, while IgG2 or 4 antibodies ( $25 \%$ of total IgG) barely do (Table 1 ) [17]. Activated leukocytes expressing Fc $\gamma$ Rs on their plasma membranes can target tumor cells by releasing cytotoxic granules or inducing phagocytosis, processes called antibody-dependent cell-mediated cytotoxicity (ADCC) or antibody-dependent cell-mediated phagocytosis (ADCP), respectively [39]. Moreover, IgG1 antibodies can maximize these antibody-mediated activities by Fc-engineering methodologies to enhance efficacy. Engineering Fc domains with enhanced affinity for activating Fc $\gamma$ Rs relative to the inhibitory Fc $\gamma$ RIIb has been attempted to strengthen ADCC or ADCP activity $[40,41]$.

In the past 15 years, Fc engineering in academia and biotechnology has been directed toward enhancing known activating Fc $\gamma$ Rs, such as Fc $\gamma$ RIIa (i.e., major contributor to ADCP activity) and Fc $\gamma$ RIIIa (i.e., major contributor to the NK ADCC activity of NK cells), relative to the inhibitory Fc $\gamma$ RIIb. For example, the biotech company Xencor (CA, USA) succeeded in engineering Fc with increased Fc $\gamma$ RIIIa binding relative to Fc $\gamma$ RIIlb compared to the endogenous human Fc. One of their mutants, S239D/I332E/A330L (EU numbering), exhibits a more than 100-fold increase in Fc $\gamma$ RIIIa binding and significantly higher ADCC activity compared to wild-type IgG Fc [42]. A distinctive Fc mutant from the same company, G236A, resulted in increased Fc $\gamma$ RIIa over Fc $\gamma$ RIIb affinity with notable ADCP activity relative to the native Fc [43]. Another biotech company, MacroGenics (MD, USA), isolated an Fc variant mutant, L235V/F243L/R292P/Y300L/P396L, with increased Fc $\gamma$ RIIIa over Fc $\gamma$ RIIb binding ratio relative to the wild-type Fc [44]. As expected, IgG antibody with mutant Fc exhibited improved ADCC activity with human peripheral blood mononuclear cells (PBMC) and NK cells as well as tumor regression in a human Fc $\gamma$ RIIIa-transgenic mice model [45]. Further, the company submitted a Biologics License Application (BLA) for FDA approval on December 2019 with successful phase 3 clinical trial with margetuximab, an mAb that adapted the Fc variant to Fab targeting Her2. Their results showed a $24 \%$ risk reduction in patients on margetuximab compared to trastuzumab in 536 patients with breast cancer [46]. Another Fc-engineered anti-CD20 antibody, ocaratuzumab, which exhibits 6-fold increased ADCC activity relative to rituximab, is being developed by Mentrik Biotech and is under phase 3 clinical trial for patients with relapsed follicular lymphoma and other oncology indications [47].

Antibody engineers have focused on using amino acid mutations to develop an IgG1 antibody FC with enhanced affinity for Fc $\gamma$ RIIIa, resulting in potentiated effector function [44,48-54]. Meanwhile, researchers in the field of glycan engineering have worked to maximize the affinity of IgG1 Fc to Fc $\gamma$ RIIIa by modifying Fc glycans such as fucose [55] and branching N-acetylglucosamine (GNAc) [56-60]. This is because the Asn297-linked carbohydrate chains on the Fc region of IgG1 are critical for Fc $\gamma$ Rs binding [61-63]. Removal of fucose on IgG1 Fc carbohydrate significantly increased Fc $\gamma$ RIIIa affinity, resulting in enhanced ADCC and ADCP activity relative to the native IgG1 FC counterpart [64]. In January 2019, the US FDA approved obinutuzumab, an afucosylated anti-CD20 antibody created by scientists at GlycArt Biotechnology, in combination with ibrutinib for first-line treatment in patients with chronic lymphocytic leukemia/small lymphocytic lymphoma [5,65]. Another example is a humanized afucosylated anti-CCR4 antibody, mogamulizumab (trade name Poteligeo), which was approved by the FDA for cutaneous T cell lymphoma (CTCL) in August 2018 [66]. These successes in oncology drug approval indicate the significance of potentiated IgG1 Fc functions for cancer therapeutics.

\section{IgG2 and 4 with Relatively Lower Effector Functions; IgG3 with a Long Hinge Region Compared to IgG1}

As mentioned above, IgG1 mAbs or antibodies with enhanced tumor-killing functions of Fc can be advantageous over native $\mathrm{Fc}_{\mathrm{c}}$ when they directly target TAAs. However, there are cases where target cell-clearance activities such as ADCC, ADCP, and/or CDC can be detrimental. For example, mAbs may act as immune-checkpoint blockers or bispecific leukocyte engagers to target tumor tissues. In these cases, constant regions with fewer effector functions are favorable $[67,68]$. To retain immune leukocytes 
that kill tumor cells, it is important to minimize the effector function of Fc so that immunosurveillance can be turned on, because $\mathrm{Fc} \gamma \mathrm{R}$ activation thresholds vary among patients. One simple way to lower $\mathrm{Fc} \gamma \mathrm{R}$ engagement is to employ the constant region of IgG2 or IgG4 because of its relatively lower Fc $\gamma \mathrm{R}$ affinity, compared to that of IgG1 (Table 1) [17,41].

IgG2 has minimal Fc $\gamma$ RIIa affinity relative to IgG1 (Table 1) and can elicit ADCC [69] and ADCP [70] by monocytes and macrophages, respectively. Because IgG2 can form four inter-heavy chain disulfide bonds (Table 1) [71] with three possible IgG2 disulfide isoforms [72], a super-agonistic property can be achieved by changing conformation of the hinge region of IgG2 [73]. The hinge region of IgG2 is most resistant to proteolysis among IgG subclasses [74]. As of January 2020, panitumumab is the only IgG2 therapeutic antibody approved by the US and EU.

IgG4 has relatively low affinity to Fc $\gamma$ RI and Fc $\gamma$ RII (Table 1) [17] and can elicit ADCP by macrophages [70] but not ADCC by NK cells [75]. IgG4 can undergo Fab-arm exchange, which results in native bispecific antibodies [76]; this has been observed in vivo [77,78]. This phenomenon can be abolished by introducing an S228P mutation that abrogates formation of intra-chain disulfide bond isomers [77,79]. Currently, the three anti-PD-1 drugs nivolumab, pembrolizumab, and cemiplimab are on US and EU markets, approved for head and neck cancer, advanced melanoma, and cutaneous squamous cell carcinoma, respectively. These antibodies share an IgG4 constant region with the S228P mutation, targeting effector $\mathrm{T}$ lymphocytes with relatively lower effector Fc functions compared to the IgG1 constant region (Table 1).

IgG3 shows the highest affinity to all the Fc $\gamma$ Rs among the IgG subclasses [17] but has a short serum half-life (Table 1) compared to IgG1 due to R435, which affects neonatal Fc receptor (FcRn) binding. This therapeutic disadvantage can be overcome by $\mathrm{R} 435 \mathrm{H}$ mutation, which is present in IgG1, 2, and 4 [80]. The main reason why there are not yet clinically available IgG3 antibodies is its 62-amino-acid long hinge region with 11 inter-heavy chain disulfide bonds (Table 1) [17], which require complex biomanufacturing and bioprocessing.

\section{Recent Findings of Fc Receptor Functions for Treating Malignancy}

A well-established function of Fc $\gamma$ RIIIa, capable of engaging NK cells and inducing ADCC activity, highlights the superior therapeutic efficacy of mAbs with Fcs engineered for higher Fc $\gamma$ RIIIa affinity relative to native IgG1 Fc $[81,82]$. Contradictorily, other studies reported that exhaustion of NK cells did not significantly lower the therapeutic efficacy of anti-CD20 mAbs [83]. Rather, macrophage depletion significantly reduced the tumor regression activity of mAbs targeting CD20 [83], CD30 [84], and CD40 [85] in mice. Together with well-known functions of macrophages in tumor phagocytic activity [86], these results indicate that ADCP activity is critical in therapeutic efficacy against cancer. The ADCP activity of macrophages is triggered by Fc $\gamma$ RIIa intracellular signaling [87-89]; however, anti-CD20 or anti-Her2 antibodies with engineered Fcs that only bind to Fc $\gamma$ RIIIa triggered not only ADCC, but also ADCP using human NK cells and macrophages in vitro, which is an unknown function of Fc $\gamma$ RIIIa [90]. This study again highlights a clinical ramification of Fc $\gamma$ RIIIa in cancer therapeutics.

The role of Fc $\gamma$ Rs in cancer therapeutics calls attention to mAbs targeting both TAAs and immune-checkpoint receptors on leukocytes. Fc $\gamma \mathrm{RIIb}$ is highlighted as an immune-checkpoint receptor in various immune cells and is considered an "antibody checkpoint" in cancer immunotherapy [91]. Furthermore, the experimental result that mice injected with Fc-engineered antibodies for enhanced $F_{c} \gamma R$ affinity exhibited survival even after re-challenge with tumor cells indicates that Fc $\gamma \mathrm{R}$ may contribute to long-term antitumor T-cell memory immunity responses [92].

When the inhibitory Fc $\gamma$ RIIb is genetically knocked out, the therapeutic efficacy of mAbs targeting CD20, Her2, and EGFR is significantly enhanced in hematologic malignancy and solid cancers [40]. This indicates that Fc $\gamma$ RIIb is an immune-checkpoint molecule similar to CTLA-4 or PD-1 in T cells $[4,12,93]$. Interestingly, Fc $\gamma$ RIIb on B cells limits the anti-tumor activity of the anti-CD20 antibody rituximab [94] and promotes internalization of the rituximab antibody [95]. This Fc $\gamma$ RIIb-mediated internalization of rituximab was correlated with receptor expression in different subtypes of B cell 
lymphoma, such as chronic lymphocytic leukemia (CLL), mantle cell lymphoma (MCL), marginal zone lymphoma, follicular lymphoma (FL), and diffuse large B cell lymphoma [96,97]. Therefore, Fc $\gamma$ RIIb seems to limit the potency of therapeutic antibody and promotes antibody drug resistance. Developing anti-Fc $\gamma$ RIIb antibodies specifically blocking the rituximab-Fc $\gamma$ RIIb interaction [98] and using them in combination with rituximab may be a decent strategy to overcome anti-CD20 drug resistance in the clinic.

Anti-CTLA-4 antibody is an immune checkpoint blocker associated with improved survival in melanoma patients having the high-affinity Fc $\gamma$ RIIIa-V158 allele to IgG Fc relative to those carrying the low affinity allele, Fc $\gamma$ RIIIa-F158 [99]. This clinical outcome of anti-CTLA-4 was expected because Fc $\gamma$ R-mediated clearance of regulatory T (Treg) cells, which express notably higher levels of CTLA-4 than effector $\mathrm{T}$ (Teff) cells, is favorable relative to that of Teff cells (Figure 2a). In the PD-1/PD-L1 axis, anti-PD-1 antibody bearing constant region of IgG1 with higher Fc $\gamma \mathrm{R}$ affinity exhibited lower therapeutic efficacy, compared to that having constant region of IgG4 [100]. This indicates that Fc $\gamma \mathrm{R}$ negatively regulates anti-PD-1 antibody therapy due to ADCC or ADCP activity on Teff cells (Figure 2b). Conversely, the therapeutic efficacy of anti-PD-L1 antibody was enhanced with the constant region of IgG1 relative to IgG4 (Table 1) due to ADCC or ADCP activity targeting PD-L1-expressing tumor cells (Figure 2c) [101].

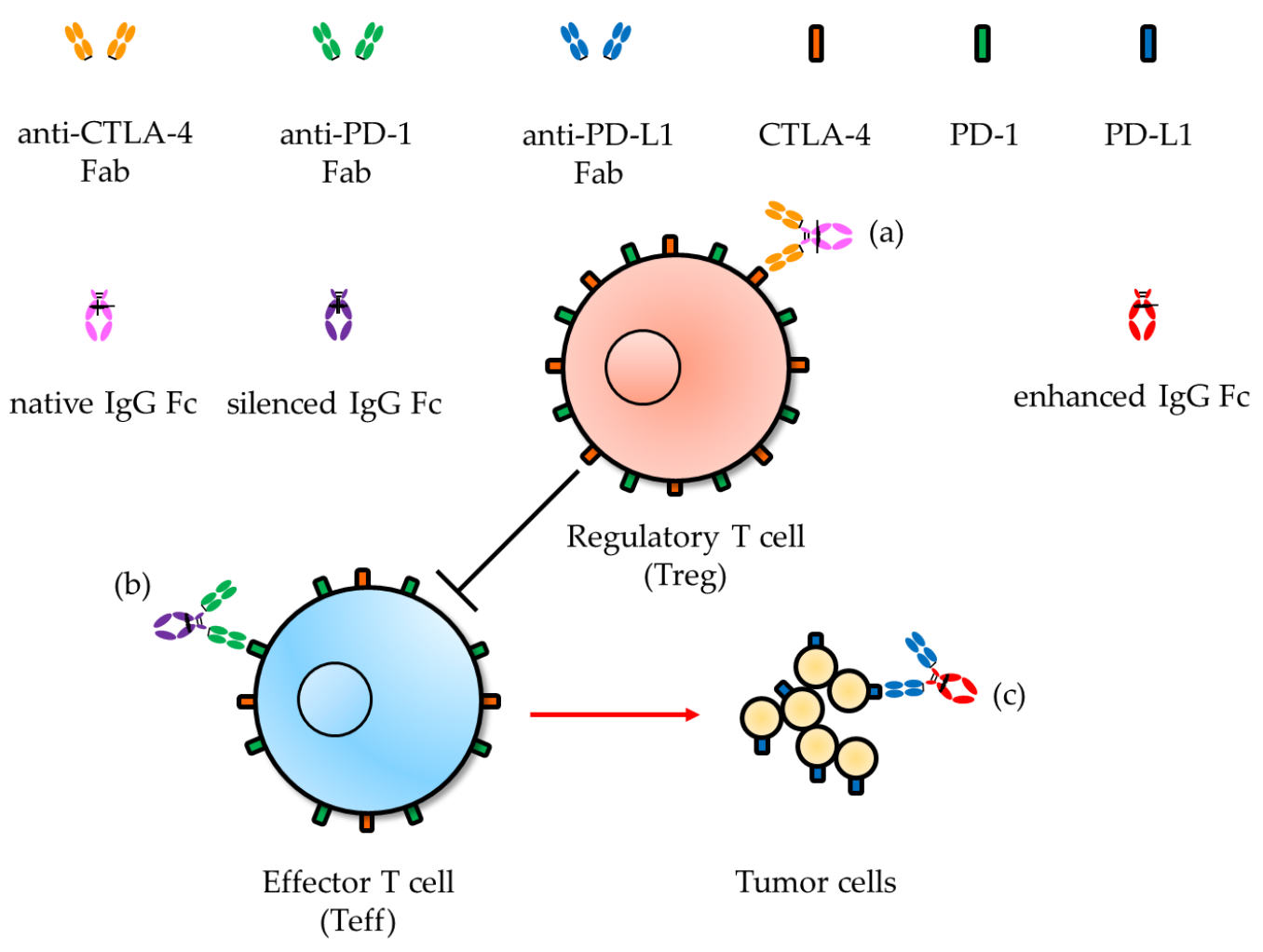

Figure 2. Proposed Fc function on immune-checkpoint blocking antibodies targeting (a) CTLA-4, with Fc $\gamma$ R-mediated clearance of regulatory T (Treg) cells; (b) PD-1, with minimized antibody-dependent cell-mediated cytotoxicity (ADCC) or antibody-dependent cell-mediated phagocytosis (ADCP) activity on effector T (Teff) cells; (c) PD-L1, with enhanced ADCC or ADCP activity on tumor cells.

\section{Future Directions for Reprogramming the Constant Region of IgG Antibodies for Treating Malignancy}

There have been beneficial clinical outcomes of Fc-engineered antibodies with enhanced affinity to Fc $\gamma$ RIIIa relative to native IgG1 Fc counterparts, including margetuximab [46], ocaratuzumab [47], obinutuzumab [65], and mogamulizumab [66]. However, it is not clear which leukocytes or Fc $\gamma$ Rs are responsible for the potentiated therapeutic results because various immune cells exhibit discrete 
Fc $\gamma R$ expression profiles [102]. In addition, every IgG1 Fc variant reprogrammed for improved affinity toward Fc $\gamma$ RIIIa also shows higher affinity to other Fc $\gamma$ Rs compared with wild-type IgG1 Fc. It not well documented which Fc $\gamma$ Rs contribute to clinical benefits, especially when considering macrophages or dendritic cells in contrast to NK cells that only express Fc $\gamma$ RIIIa (CD16a) [102]. This is important because intra-tumoral macrophages [95] and dendritic cells are critical as anti-tumoral immune effectors [103].

Fc $\gamma$ RIIa and Fc $\gamma$ RIIb are expressed relatively highly in macrophages and dendritic cells compared to other Fc $\gamma$ Rs [99]. Moreover, Fc $\gamma$ RIIa is the only activating Fc $\gamma$ R on the plasma membrane of human dendritic cells, while Fc $\gamma$ RIIb on the same cells regulates antigen presentation in collaboration with Fc $\gamma$ RIIa [104]. Therefore, it is critical to define the functions of Fc $\gamma$ RIIa and Fc $\gamma$ RIIb on various types of immune cells, especially macrophages and dendritic cells. For this purpose, an Fc that selectively binds to Fc $\gamma$ RIIa and Fc $\gamma$ RIIb is essential (Figure 3). Fc $\gamma$ R-selective antibodies are advantageous over blocking antibodies or siRNAs because they will elucidate direct functions of antibody-mediated activity rather than just providing indirect evidence by inhibiting intracellular signal cascades; however, neither Fc $\gamma$ RIIa- nor Fc $\gamma$ RIIb-selective Fc is available at present. Engineering of Fc $\gamma$ R-selective Fc may be challenging, as the amino acid sequences of Fc $\gamma$ R ecto-domains are highly homologous (Fc $\gamma$ RIIa and Fc $\gamma$ RIlb exhibit 96\% identity in amino acid sequence) [105].
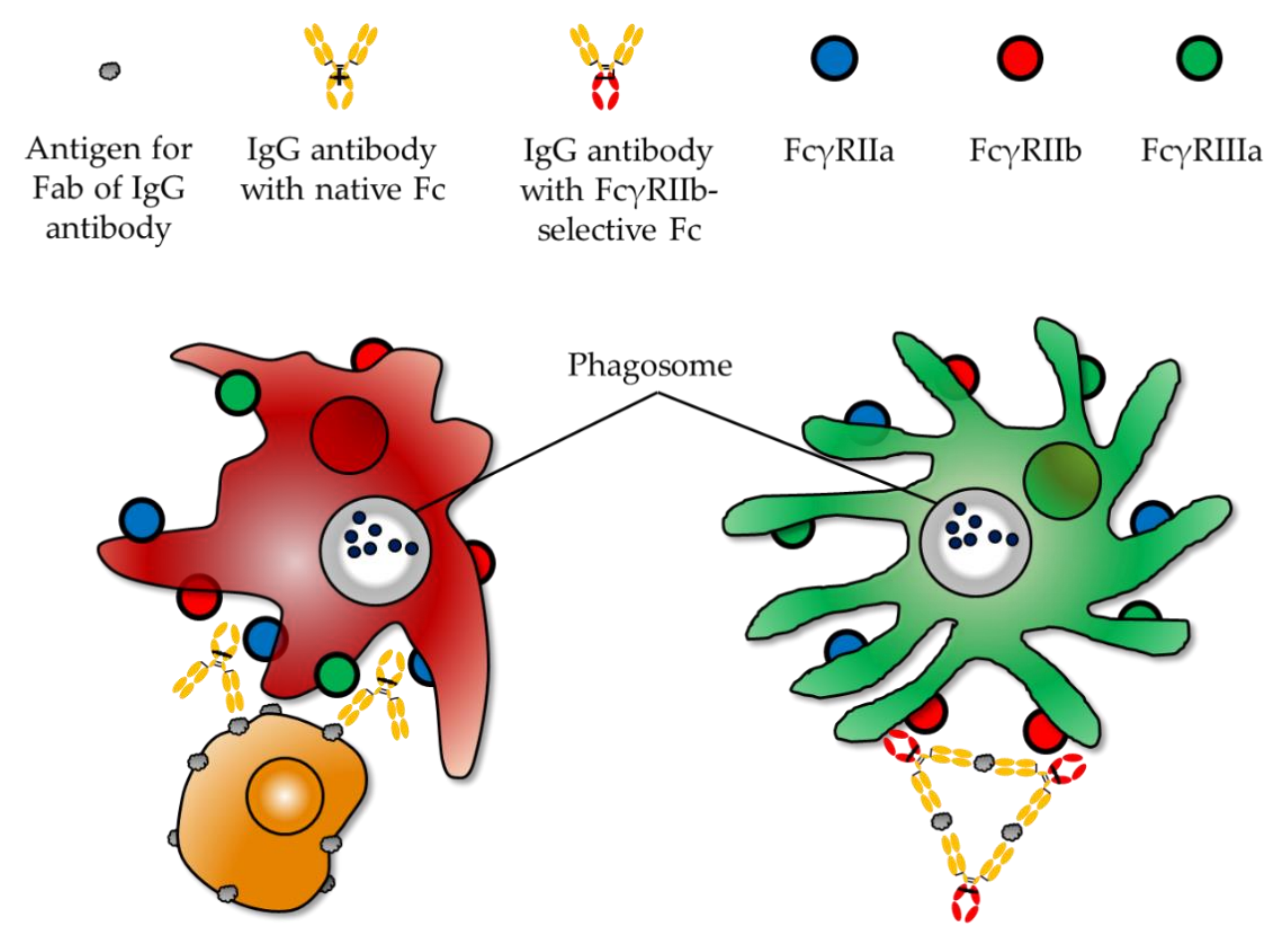

(a)

(b)

Figure 3. To elucidate $F_{c}$ function, $F_{c} \gamma$ R-selective $F_{c}$ should be present. (a) Native IgG antibodies engage all types of Fc $\gamma$ Rs, making it very difficult to dissect the function of each Fc $\gamma R$ in macrophages until the Fc $\gamma$ R-selective IgG antibody is present; (b) Fc $\gamma$ RIIb function in dendritic cells can only be clarified in the presence of Fc $\gamma$ RIIb-selective IgG antibody.

With the precedent of Fc $\gamma$ RI- and Fc $\gamma$ RIIIa-selective Fcs [90,106], Fc $\gamma$ RIIa- and Fc $\gamma$ RIIb-selective Fcs should be developed to dissect antibody-mediated effector mechanisms for understanding human immunobiology and providing future antibody therapeutics. These selective Fcs are designed for (i) tumor cell destruction, such as anti-CD20 antibodies [5], (ii) immune cell activation, such as agonistic anti-CD40 [107,108] or anti-TNFR antibodies [109], which elicit antigen presentation and subsequent adaptive immune response by engaging $\mathrm{Fc} \gamma \mathrm{RIIb}$, and (iii) anti-tumor vaccine effect [92]. Fc $\gamma$ Rs have 
been demonstrated to contribute to the adaptive memory immune response. However, it is not possible to determine which Fc $\gamma$ Rs are responsible for long-term anti-tumor immunity until full sets of Fc $\gamma$ Rs-specific Fcs are present.

Now that mouse models in which not only the murine Fc $\gamma \mathrm{R}$ genes have been exchanged with human counterparts $[110,111]$ but also the murine $\mu$ region of heavy chain and kappa regions of Ig light chain genes have been exchanged with human IgG constant heavy regions and human $\mathrm{k}$ light region genes, respectively [112], are available, Fc $\gamma$ Rs-specific IgG antibodies can be developed to indicate the contribution of $\mathrm{Fc} \gamma \mathrm{R}$ to long-term anti-tumor efficacy using these mouse models. This work has previously been evaluated [92] but since IgG antibodies used in the study were not strictly Fc $\gamma$ Rs-specific, we cannot draw any conclusion on which Fc $\gamma R$ is responsible for long-term anti-cancer efficacy. The animal models can be very useful to elucidate the Fc $\gamma R$ function in adaptive immunity; however, they have limitations in the immunobiology of a mouse, such that murine Fc $\gamma \mathrm{R}$ expression profiles on murine immune leukocytes cannot be translated into that of humans.

\section{Conclusions}

Capitalizing on native IgG1 subclass or engineered constant regions of IgG is a potent strategy used to potentiate therapeutic efficacy that has had several clinical successes, including approval of antibody drugs with significant or even improved affinity to activating Fc $\gamma$ Rs. On the contrary, IgG2, IgG4, or even mutant constant regions to silence effector functions are required for antibody cancer therapy, especially when a drug targets immune-checkpoint molecules on effector leukocytes. However, it is not yet clear which Fc $\gamma$ Rs and which immune effector cells are responsible for anti-tumor efficacy. Fc $\gamma$ R-selective Fcs are prerequisites for this elucidation, as antibodies that selectively activate each Fc $\gamma \mathrm{R}$ will directly gain immune function. Once the function of an IgG constant region becomes clear by Fc reprogramming, antibody platforms can be developed to broaden therapeutic windows for cancer treatment.

Author Contributions: T.H.K. and S.T.J. designed and wrote the paper. All authors have read and agreed to the published version of the manuscript.

Funding: This work was supported by grants from the Bio \& Medical Technology Development Program (2017M3A9C8060541), the Basic Science Research Programs (2019R1F1A1059834 and 2019R1A4A1029000) through the National Research Foundation of Korea funded by the Ministry of Science and ICT, and LG Chem Open Innovation Fund.

Conflicts of Interest: The authors declare no conflicts of interest.

\section{References}

1. Blockbuster Biologics 2018: Sales of Recombinant Therapeutic Antibodies \& Proteins. LMCA0175 2019.

2. The Antibody Society. Available online: https://www.antibodysociety.org/resources/approved-antibodies/ (accessed on 6 February 2020).

3. Grilo, A.L.; Mantalaris, A. The increasingly human and profitable monoclonal antibody market. Trends Biotechnol. 2019, 37, 9-16. [CrossRef] [PubMed]

4. Sharma, P.; Hu-Lieskovan, S.; Wargo, J.A.; Ribas, A. Primary, Adaptive, and Acquired Resistance to Cancer Immunotherapy. Cell 2017, 168, 707-723. [CrossRef] [PubMed]

5. Goede, V.; Fischer, K.; Busch, R.; Engelke, A.; Eichhorst, B.; Wendtner, C.M.; Chagorova, T.; de la Serna, J.; Dilhuydy, M.S.; Illmer, T.; et al. Obinutuzumab plus chlorambucil in patients with CLL and coexisting conditions. N. Engl. J. Med. 2014, 370, 1101-1110. [CrossRef] [PubMed]

6. Baselga, J.; Cortes, J.; Kim, S.B.; Im, S.A.; Hegg, R.; Im, Y.H.; Roman, L.; Pedrini, J.L.; Pienkowski, T.; Knott, A.; et al. Pertuzumab plus trastuzumab plus docetaxel for metastatic breast cancer. N. Engl. J. Med. 2012, 366, 109-119. [CrossRef] [PubMed]

7. Gopal, A.K.; Kahl, B.S.; de Vos, S.; Wagner-Johnston, N.D.; Schuster, S.J.; Jurczak, W.J.; Flinn, I.W.; Flowers, C.R.; Martin, P.; Viardot, A.; et al. PI3Kdelta inhibition by idelalisib in patients with relapsed indolent lymphoma. N. Engl. J. Med. 2014, 370, 1008-1018. [CrossRef] 
8. Cheson, B.D.; Leonard, J.P. Monoclonal antibody therapy for B-cell non-Hodgkin's lymphoma. N. Engl. J. Med. 2008, 359, 613-626. [CrossRef]

9. Gradishar, W.J. HER2 therapy-An abundance of riches. N. Engl. J. Med. 2012, 366, 176-178. [CrossRef]

10. Jonker, D.J.; O'Callaghan, C.J.; Karapetis, C.S.; Zalcberg, J.R.; Tu, D.; Au, H.J.; Berry, S.R.; Krahn, M.; Price, T.; Simes, R.J.; et al. Cetuximab for the treatment of colorectal cancer. N. Engl. J. Med. 2007, 357, 2040-2048. [CrossRef]

11. Lokhorst, H.M.; Plesner, T.; Laubach, J.P.; Nahi, H.; Gimsing, P.; Hansson, M.; Minnema, M.C.; Lassen, U.; Krejcik, J.; Palumbo, A.; et al. Targeting CD38 with Daratumumab Monotherapy in Multiple Myeloma. N. Engl. J. Med. 2015, 373, 1207-1219. [CrossRef]

12. Larkin, J.; Chiarion-Sileni, V.; Gonzalez, R.; Grob, J.J.; Cowey, C.L.; Lao, C.D.; Schadendorf, D.; Dummer, R.; Smylie, M.; Rutkowski, P.; et al. Combined Nivolumab and Ipilimumab or Monotherapy in Untreated Melanoma. N. Engl. J. Med 2015, 373, 23-34. [CrossRef] [PubMed]

13. Ribas, A.; Puzanov, I.; Dummer, R.; Schadendorf, D.; Hamid, O.; Robert, C.; Hodi, F.S.; Schachter, J.; Pavlick, A.C.; Lewis, K.D.; et al. Pembrolizumab versus investigator-choice chemotherapy for ipilimumab-refractory melanoma (KEYNOTE-002): A randomised, controlled, phase 2 trial. Lancet Oncol. 2015, 16, 908-918. [CrossRef]

14. Robert, C.; Ribas, A.; Wolchok, J.D.; Hodi, F.S.; Hamid, O.; Kefford, R.; Weber, J.S.; Joshua, A.M.; $\mathrm{Hwu}$, W.J.; Gangadhar, T.C.; et al. Anti-programmed-death-receptor-1 treatment with pembrolizumab in ipilimumab-refractory advanced melanoma: A randomised dose-comparison cohort of a phase 1 trial. Lancet 2014, 384, 1109-1117. [CrossRef]

15. Robert, C.; Long, G.V.; Brady, B.; Dutriaux, C.; Maio, M.; Mortier, L.; Hassel, J.C.; Rutkowski, P.; McNeil, C.; Kalinka-Warzocha, E.; et al. Nivolumab in previously untreated melanoma without BRAF mutation. N. Engl. J. Med. 2015, 372, 320-330. [CrossRef]

16. Weber, J.S.; D’Angelo, S.P.; Minor, D.; Hodi, F.S.; Gutzmer, R.; Neyns, B.; Hoeller, C.; Khushalani, N.I.; Miller, W.H.; Lao, C.D.; et al. Nivolumab versus chemotherapy in patients with advanced melanoma who progressed after anti-CTLA-4 treatment (CheckMate 037): A randomised, controlled, open-label, phase 3 trial. Lancet Oncol. 2015, 16, 375-384. [CrossRef]

17. Bruhns, P.; Iannascoli, B.; England, P.; Mancardi, D.A.; Fernandez, N.; Jorieux, S.; Daeron, M. Specificity and affinity of human Fcgamma receptors and their polymorphic variants for human IgG subclasses. Blood 2009, 113, 3716-3725. [CrossRef]

18. Brezski, R.J.; Georgiou, G. Immunoglobulin isotype knowledge and application to Fc engineering. Curr. Opin. Immunol. 2016, 40, 62-69. [CrossRef]

19. Nimmerjahn, F.; Ravetch, J.V. Fcgamma receptors as regulators of immune responses. Nat. Rev. Immunol. 2008, 8, 34-47. [CrossRef]

20. Ravetch, J.V.; Lanier, L.L. Immune inhibitory receptors. Science 2000, 290, 84-89. [CrossRef]

21. Ravetch, J.V.; Bolland, S. IgG Fc receptors. Annu. Rev. Immunol. 2001, 19, 275-290. [CrossRef]

22. Berken, A.; Benacerraf, B. Properties of antibodies cytophilic for macrophages. J. Exp. Med. 1966, 123, 119-144. [CrossRef] [PubMed]

23. Takai, T. FC receptors and their role in immune regulation and autoimmunity. J. Clin. Immunol. 2005, 25, 1-18. [CrossRef] [PubMed]

24. Ivan, E.; Colovai, A.I. Human Fc receptors: Critical targets in the treatment of autoimmune diseases and transplant rejections. Hum. Immunol. 2006, 67, 479-491. [CrossRef] [PubMed]

25. Cohen-Solal, J.F.; Cassard, L.; Fridman, W.H.; Sautes-Fridman, C. Fc gamma receptors. Immunol. Lett. 2004, 92, 199-205. [CrossRef] [PubMed]

26. Nimmerjahn, F.; Ravetch, J.V. Fcgamma receptors: Old friends and new family members. Immunity 2006, 24, 19-28. [CrossRef]

27. Krapp, S.; Mimura, Y.; Jefferis, R.; Huber, R.; Sondermann, P. Structural analysis of human IgG-Fc glycoforms reveals a correlation between glycosylation and structural integrity. J. Mol. Biol. 2003, 325, 979-989. [CrossRef]

28. van der Pol, W.L.; van de Winkel, J.G. Immunology in clinical practice. X. IgG receptors: Structure, function and immunotherapy. Ned. Tijdschr. Geneeskd. 1998, 142, 335-340.

29. Allen, J.M.; Seed, B. Isolation and expression of functional high-affinity Fc receptor complementary DNAs. Science 1989, 243, 378-381. [CrossRef] 
30. Kuster, H.; Thompson, H.; Kinet, J.P. Characterization and expression of the gene for the human Fc receptor gamma subunit. Definition of a new gene family. J. Biol. Chem. 1990, 265, 6448-6452.

31. Cassel, D.L.; Keller, M.A.; Surrey, S.; Schwartz, E.; Schreiber, A.D.; Rappaport, E.F.; McKenzie, S.E. Differential expression of Fc gamma RIIA, Fc gamma RIIB and Fc gamma RIIC in hematopoietic cells: Analysis of transcripts. Mol. Immunol. 1993, 30, 451-460. [CrossRef]

32. Phillips, N.E.; Parker, D.C. Fc-dependent inhibition of mouse B cell activation by whole anti-mu antibodies. J. Immunol. 1983, 130, 602-606. [PubMed]

33. Salmon, J.E.; Millard, S.S.; Brogle, N.L.; Kimberly, R.P. Fc gamma receptor IIIb enhances Fc gamma receptor IIa function in an oxidant-dependent and allele-sensitive manner. J. Clin. Investig. 1995, 95, 2877-2885. [CrossRef] [PubMed]

34. Gessner, J.E.; Heiken, H.; Tamm, A.; Schmidt, R.E. The IgG Fc receptor family. Ann. Hematol. 1998, 76, 231-248. [CrossRef]

35. Siberil, S.; Dutertre, C.A.; Fridman, W.H.; Teillaud, J.L. FcgammaR: The key to optimize therapeutic antibodies? Crit. Rev. Oncol. Hematol. 2007, 62, 26-33. [CrossRef] [PubMed]

36. Huber, R.; Deisenhofer, J.; Colman, P.M.; Matsushima, M.; Palm, W. Crystallographic structure studies of an IgG molecule and an Fc fragment. Nature 1976, 264, 415-420. [CrossRef]

37. Bournazos, S. IgG Fc Receptors: Evolutionary Considerations. Curr. Top. Microbiol. Immunol. 2019, 423, 1-11. [CrossRef]

38. French, M. Serum IgG subclasses in normal adults. Monogr. Allergy 1986, 19, 100-107.

39. Park, H.I.; Yoon, H.W.; Jung, S.T. The Highly Evolvable Antibody Fc Domain. Trends Biotechnol. 2016, 34 , 895-908. [CrossRef]

40. Clynes, R.A.; Towers, T.L.; Presta, L.G.; Ravetch, J.V. Inhibitory Fc receptors modulate in vivo cytotoxicity against tumor targets. Nat. Med. 2000, 6, 443-446. [CrossRef]

41. Nimmerjahn, F.; Ravetch, J.V. Divergent immunoglobulin g subclass activity through selective Fc receptor binding. Science 2005, 310, 1510-1512. [CrossRef]

42. Lazar, G.A.; Dang, W.; Karki, S.; Vafa, O.; Peng, J.S.; Hyun, L.; Chan, C.; Chung, H.S.; Eivazi, A.; Yoder, S.C.; et al. Engineered antibody Fc variants with enhanced effector function. Proc. Natl. Acad. Sci. USA 2006, 103, 4005-4010. [CrossRef] [PubMed]

43. Richards, J.O.; Karki, S.; Lazar, G.A.; Chen, H.; Dang, W.; Desjarlais, J.R. Optimization of antibody binding to FcgammaRIIa enhances macrophage phagocytosis of tumor cells. Mol. Cancer Ther. 2008, 7, 2517-2527. [CrossRef] [PubMed]

44. Stavenhagen, J.B.; Gorlatov, S.; Tuaillon, N.; Rankin, C.T.; Li, H.; Burke, S.; Huang, L.; Johnson, S.; Koenig, S.; Bonvini, E. Enhancing the potency of therapeutic monoclonal antibodies via Fc optimization. Adv. Enzyme Regul. 2008, 48, 152-164. [CrossRef] [PubMed]

45. Nordstrom, J.L.; Gorlatov, S.; Zhang, W.; Yang, Y.; Huang, L.; Burke, S.; Li, H.; Ciccarone, V.; Zhang, T.; Stavenhagen, J.; et al. Anti-tumor activity and toxicokinetics analysis of MGAH22, an anti-HER2 monoclonal antibody with enhanced Fcgamma receptor binding properties. Breast Cancer Res. 2011, 13, R123. [CrossRef]

46. Taylor, N.P. MacroGenics' margetuximab beats Herceptin in phase 3. FierceBiotech 2019.

47. VanDerMeid, K.R.; Elliott, M.R.; Baran, A.M.; Barr, P.M.; Chu, C.C.; Zent, C.S. Cellular Cytotoxicity of Next-Generation CD20 Monoclonal Antibodies. Cancer Immunol. Res. 2018, 6, 1150-1160. [CrossRef]

48. Shields, R.L.; Namenuk, A.K.; Hong, K.; Meng, Y.G.; Rae, J.; Briggs, J.; Xie, D.; Lai, J.; Stadlen, A.; Li, B.; et al. High resolution mapping of the binding site on human IgG1 for Fc gamma RI, Fc gamma RII, Fc gamma RIII, and FcRn and design of IgG1 variants with improved binding to the Fc gamma R. J. Biol. Chem. 2001, 276, 6591-6604. [CrossRef]

49. Oganesyan, V.; Damschroder, M.M.; Leach, W.; Wu, H.; Dall'Acqua, W.F. Structural characterization of a mutated, ADCC-enhanced human Fc fragment. Mol. Immunol. 2008, 45, 1872-1882. [CrossRef]

50. Saxena, A.; Wu, D. Advances in Therapeutic Fc Engineering-Modulation of IgG-Associated Effector Functions and Serum Half-life. Front. Immunol. 2016, 7, 580. [CrossRef]

51. Ashoor, D.N.; Ben Khalaf, N.; Bourguiba-Hachemi, S.; Marzouq, M.H.; Fathallah, M.D. Engineering of the upper hinge region of human IgG1 Fc enhances the binding affinity to FcgammaIIIa (CD16a) receptor isoform. Protein. Eng. Des. Sel. 2018, 31, 205-212. [CrossRef]

52. Zhang, D.; Goldberg, M.V.; Chiu, M.L. Fc Engineering Approaches to Enhance the Agonism and Effector Functions of an Anti-OX40 Antibody. J. Biol. Chem. 2016, 291, 27134-27146. [CrossRef] [PubMed] 
53. Jo, M.; Kwon, H.S.; Lee, K.H.; Lee, J.C.; Jung, S.T. Engineered aglycosylated full-length IgG Fc variants exhibiting improved FcgammaRIIIa binding and tumor cell clearance. MAbs 2018, 10, 278-289. [CrossRef] [PubMed]

54. Yoon, H.W.; Jo, M.; Ko, S.; Kwon, H.S.; Lim, C.S.; Ko, B.J.; Lee, J.C.; Jung, S.T. Optimal combination of beneficial mutations for improved ADCC effector function of aglycosylated antibodies. Mol. Immunol. 2019, 114, 62-71. [CrossRef] [PubMed]

55. Shields, R.L.; Lai, J.; Keck, R.; O'Connell, L.Y.; Hong, K.; Meng, Y.G.; Weikert, S.H.; Presta, L.G. Lack of fucose on human IgG1 N-linked oligosaccharide improves binding to human Fcgamma RIII and antibody-dependent cellular toxicity. J. Biol. Chem. 2002, 277, 26733-26740. [CrossRef] [PubMed]

56. Li, T.; DiLillo, D.J.; Bournazos, S.; Giddens, J.P.; Ravetch, J.V.; Wang, L.X. Modulating IgG effector function by Fc glycan engineering. Proc. Natl. Acad. Sci. USA 2017, 114, 3485-3490. [CrossRef] [PubMed]

57. Li, W.; Zhu, Z.; Chen, W.; Feng, Y.; Dimitrov, D.S. Crystallizable Fragment Glycoengineering for Therapeutic Antibodies Development. Front. Immunol. 2017, 8, 1554. [CrossRef]

58. Umana, P.; Jean-Mairet, J.; Moudry, R.; Amstutz, H.; Bailey, J.E. Engineered glycoforms of an antineuroblastoma IgG1 with optimized antibody-dependent cellular cytotoxic activity. Nat. Biotechnol. 1999, 17, 176-180. [CrossRef]

59. Yu, X.; Marshall, M.J.E.; Cragg, M.S.; Crispin, M. Improving Antibody-Based Cancer Therapeutics Through Glycan Engineering. BioDrugs 2017, 31, 151-166. [CrossRef]

60. Peschke, B.; Keller, C.W.; Weber, P.; Quast, I.; Lunemann, J.D. Fc-Galactosylation of Human Immunoglobulin Gamma Isotypes Improves C1q Binding and Enhances Complement-Dependent Cytotoxicity. Front. Immunol. 2017, 8, 646. [CrossRef]

61. Fang, J.; Richardson, J.; Du, Z.; Zhang, Z. Effect of Fc-Glycan Structure on the Conformational Stability of IgG Revealed by Hydrogen/Deuterium Exchange and Limited Proteolysis. Biochemistry 2016, 55, 860-868. [CrossRef]

62. Kiyoshi, M.; Tsumoto, K.; Ishii-Watabe, A.; Caaveiro, J.M.M. Glycosylation of IgG-Fc: A molecular perspective. Int. Immunol. 2017, 29, 311-317. [CrossRef] [PubMed]

63. Lee, H.S.; Im, W. Effects of N-Glycan Composition on Structure and Dynamics of IgG1 Fc and Their Implications for Antibody Engineering. Sci. Rep. 2017, 7, 12659. [CrossRef] [PubMed]

64. Liu, S.D.; Chalouni, C.; Young, J.C.; Junttila, T.T.; Sliwkowski, M.X.; Lowe, J.B. Afucosylated antibodies increase activation of FcgammaRIIIa-dependent signaling components to intensify processes promoting ADCC. Cancer Immunol. Res. 2015, 3, 173-183. [CrossRef] [PubMed]

65. Rogers, K.A.; Huang, Y.; Ruppert, A.S.; Awan, F.T.; Heerema, N.A.; Hoffman, C.; Lozanski, G.; Maddocks, K.J.; Moran, M.E.; Reid, M.A.; et al. Phase $1 b$ study of obinutuzumab, ibrutinib, and venetoclax in relapsed and refractory chronic lymphocytic leukemia. Blood 2018, 132, 1568-1572. [CrossRef] [PubMed]

66. Alpdogan, O.; Kartan, S.; Johnson, W.; Sokol, K.; Porcu, P. Systemic therapy of cutaneous T-cell lymphoma (CTCL). Chin. Clin. Oncol. 2019, 8, 10. [CrossRef]

67. Strohl, W.R. Optimization of Fc-mediated effector functions of monoclonal antibodies. Curr. Opin. Biotechnol. 2009, 20, 685-691. [CrossRef]

68. Kontermann, R.E.; Brinkmann, U. Bispecific antibodies. Drug Discov. Today 2015, 20, 838-847. [CrossRef]

69. Schneider-Merck, T.; Lammerts van Bueren, J.J.; Berger, S.; Rossen, K.; van Berkel, P.H.; Derer, S.; Beyer, T.; Lohse, S.; Bleeker, W.K.; Peipp, M.; et al. Human IgG2 antibodies against epidermal growth factor receptor effectively trigger antibody-dependent cellular cytotoxicity but, in contrast to IgG1, only by cells of myeloid lineage. J. Immunol. 2010, 184, 512-520. [CrossRef]

70. Kinder, M.; Greenplate, A.R.; Strohl, W.R.; Jordan, R.E.; Brezski, R.J. An Fc engineering approach that modulates antibody-dependent cytokine release without altering cell-killing functions. MAbs 2015, 7, 494-504. [CrossRef]

71. Dillon, T.M.; Ricci, M.S.; Vezina, C.; Flynn, G.C.; Liu, Y.D.; Rehder, D.S.; Plant, M.; Henkle, B.; Li, Y.; Deechongkit, S.; et al. Structural and functional characterization of disulfide isoforms of the human IgG2 subclass. J. Biol. Chem. 2008, 283, 16206-16215. [CrossRef]

72. Liu, H.; May, K. Disulfide bond structures of IgG molecules: Structural variations, chemical modifications and possible impacts to stability and biological function. MAbs 2012, 4, 17-23. [CrossRef] [PubMed] 
73. White, A.L.; Chan, H.T.; French, R.R.; Willoughby, J.; Mockridge, C.I.; Roghanian, A.; Penfold, C.A.; Booth, S.G.; Dodhy, A.; Polak, M.E.; et al. Conformation of the human immunoglobulin G2 hinge imparts superagonistic properties to immunostimulatory anticancer antibodies. Cancer Cell 2015, 27, 138-148. [CrossRef] [PubMed]

74. Brezski, R.J.; Oberholtzer, A.; Strake, B.; Jordan, R.E. The in vitro resistance of IgG2 to proteolytic attack concurs with a comparative paucity of autoantibodies against peptide analogs of the IgG2 hinge. MAbs 2011, 3, 558-567. [CrossRef] [PubMed]

75. Brezski, R.J.; Kinder, M.; Grugan, K.D.; Soring, K.L.; Carton, J.; Greenplate, A.R.; Petley, T.; Capaldi, D.; Brosnan, K.; Emmell, E.; et al. A monoclonal antibody against hinge-cleaved IgG restores effector function to proteolytically-inactivated IgGs in vitro and in vivo. MAbs 2014, 6, 1265-1273. [CrossRef]

76. Aalberse, R.C.; Schuurman, J. IgG4 breaking the rules. Immunology 2002, 105, 9-19. [CrossRef]

77. Labrijn, A.F.; Buijsse, A.O.; van den Bremer, E.T.; Verwilligen, A.Y.; Bleeker, W.K.; Thorpe, S.J.; Killestein, J.; Polman, C.H.; Aalberse, R.C.; Schuurman, J.; et al. Therapeutic IgG4 antibodies engage in Fab-arm exchange with endogenous human IgG4 in vivo. Nat. Biotechnol. 2009, 27, 767-771. [CrossRef]

78. van der Neut Kolfschoten, M.; Schuurman, J.; Losen, M.; Bleeker, W.K.; Martinez-Martinez, P.; Vermeulen, E.; den Bleker, T.H.; Wiegman, L.; Vink, T.; Aarden, L.A.; et al. Anti-inflammatory activity of human IgG4 antibodies by dynamic Fab arm exchange. Science 2007, 317, 1554-1557. [CrossRef]

79. Angal, S.; King, D.J.; Bodmer, M.W.; Turner, A.; Lawson, A.D.; Roberts, G.; Pedley, B.; Adair, J.R. A single amino acid substitution abolishes the heterogeneity of chimeric mouse/human (IgG4) antibody. Mol. Immunol. 1993, 30, 105-108. [CrossRef]

80. Stapleton, N.M.; Andersen, J.T.; Stemerding, A.M.; Bjarnarson, S.P.; Verheul, R.C.; Gerritsen, J.; Zhao, Y.; Kleijer, M.; Sandlie, I.; de Haas, M.; et al. Competition for FcRn-mediated transport gives rise to short half-life of human IgG3 and offers therapeutic potential. Nat. Commun. 2011, 2, 599. [CrossRef]

81. Hatjiharissi, E.; Xu, L.; Santos, D.D.; Hunter, Z.R.; Ciccarelli, B.T.; Verselis, S.; Modica, M.; Cao, Y.; Manning, R.J.; Leleu, X.; et al. Increased natural killer cell expression of CD16, augmented binding and ADCC activity to rituximab among individuals expressing the Fc $\gamma$ RIIIa-158 V/V and V/F polymorphism. Blood 2007, 110, 2561-2564. [CrossRef]

82. Capuano, C.; Pighi, C.; Molfetta, R.; Paolini, R.; Battella, S.; Palmieri, G.; Giannini, G.; Belardinilli, F.; Santoni, A.; Galandrini, R. Obinutuzumab-mediated high-affinity ligation of FcgammaRIIIA/CD16 primes NK cells for IFNgamma production. Oncoimmunology 2017, 6, e1290037. [CrossRef] [PubMed]

83. Horikawa, M.; Minard-Colin, V.; Matsushita, T.; Tedder, T.F. Regulatory B cell production of IL-10 inhibits lymphoma depletion during CD20 immunotherapy in mice. J. Clin. Investig. 2011, 121, 4268-4280. [CrossRef] [PubMed]

84. Oflazoglu, E.; Stone, I.J.; Gordon, K.A.; Grewal, I.S.; van Rooijen, N.; Law, C.L.; Gerber, H.P. Macrophages contribute to the antitumor activity of the anti-CD30 antibody SGN-30. Blood 2007, 110, 4370-4372. [CrossRef]

85. Oflazoglu, E.; Stone, I.J.; Brown, L.; Gordon, K.A.; van Rooijen, N.; Jonas, M.; Law, C.L.; Grewal, I.S.; Gerber, H.P. Macrophages and Fc-receptor interactions contribute to the antitumour activities of the anti-CD40 antibody SGN-40. Brit. J. Cancer 2009, 100, 113-117. [CrossRef] [PubMed]

86. Gul, N.; Babes, L.; Siegmund, K.; Korthouwer, R.; Bogels, M.; Braster, R.; Vidarsson, G.; ten Hagen, T.L.; Kubes, P.; van Egmond, M. Macrophages eliminate circulating tumor cells after monoclonal antibody therapy. J. Clin. Investig. 2014, 124, 812-823. [CrossRef] [PubMed]

87. Dahal, L.N.; Dou, L.; Hussain, K.; Liu, R.; Earley, A.; Cox, K.L.; Murinello, S.; Tracy, I.; Forconi, F.; Steele, A.J.; et al. STING Activation Reverses Lymphoma-Mediated Resistance to Antibody Immunotherapy. Cancer Res. 2017, 77, 3619-3631. [CrossRef]

88. Nagelkerke, S.Q.; Bruggeman, C.W.; den Haan, J.M.M.; Mul, E.P.J.; van den Berg, T.K.; van Bruggen, R.; Kuijpers, T.W. Red pulp macrophages in the human spleen are a distinct cell population with a unique expression of Fc-gamma receptors. Blood Adv. 2018, 2, 941-953. [CrossRef]

89. Martinez, F.O.; Sica, A.; Mantovani, A.; Locati, M. Macrophage activation and polarization. Front. Biosci. 2008, 13, 453-461. [CrossRef]

90. Kang, T.H.; Lee, C.H.; Delidakis, G.; Jung, J.; Richard-Le Goff, O.; Lee, J.; Kim, J.E.; Charab, W.; Bruhns, P.; Georgiou, G. An Engineered Human Fc variant With Exquisite Selectivity for FcgammaRIIIaV158 Reveals That Ligation of FcgammaRIIIa Mediates Potent Antibody Dependent Cellular Phagocytosis With GM-CSF-Differentiated Macrophages. Front. Immunol. 2019, 10, 562. [CrossRef] 
91. Teige, I.; Martensson, L.; Frendeus, B.L. Targeting the Antibody Checkpoints to Enhance Cancer Immunotherapy-Focus on FcgammaRIIB. Front. Immunol. 2019, 10, 481. [CrossRef]

92. DiLillo, D.J.; Ravetch, J.V. Differential Fc-Receptor Engagement Drives an Anti-tumor Vaccinal Effect. Cell 2015, 161, 1035-1045. [CrossRef] [PubMed]

93. Postow, M.A.; Chesney, J.; Pavlick, A.C.; Robert, C.; Grossmann, K.; McDermott, D.; Linette, G.P.; Meyer, N.; Giguere, J.K.; Agarwala, S.S.; et al. Nivolumab and ipilimumab versus ipilimumab in untreated melanoma. N. Engl. J. Med. 2015, 372, 2006-2017. [CrossRef]

94. Roghanian, A.; Teige, I.; Martensson, L.; Cox, K.L.; Kovacek, M.; Ljungars, A.; Mattson, J.; Sundberg, A.; Vaughan, A.T.; Shah, V.; et al. Antagonistic human FcgammaRIIB (CD32B) antibodies have anti-tumor activity and overcome resistance to antibody therapy in vivo. Cancer Cell 2015, 27, 473-488. [CrossRef] [PubMed]

95. Beers, S.A.; French, R.R.; Chan, H.T.; Lim, S.H.; Jarrett, T.C.; Vidal, R.M.; Wijayaweera, S.S.; Dixon, S.V.; Kim, H.; Cox, K.L.; et al. Antigenic modulation limits the efficacy of anti-CD20 antibodies: Implications for antibody selection. Blood 2010, 115, 5191-5201. [CrossRef] [PubMed]

96. Lim, S.H.; Vaughan, A.T.; Ashton-Key, M.; Williams, E.L.; Dixon, S.V.; Chan, H.T.; Beers, S.A.; French, R.R.; Cox, K.L.; Davies, A.J.; et al. Fc gamma receptor IIb on target B cells promotes rituximab internalization and reduces clinical efficacy. Blood 2011, 118, 2530-2540. [CrossRef] [PubMed]

97. Camilleri-Broet, S.; Cassard, L.; Broet, P.; Delmer, A.; Le Touneau, A.; Diebold, J.; Fridman, W.H.; Molina, T.J.; Sautes-Fridman, C. FcgammaRIIB is differentially expressed during B cell maturation and in B-cell lymphomas. Br. J. Haematol. 2004, 124, 55-62. [CrossRef]

98. Johnson, L.S.; Huang, L.; Gerena, R. FcgammaRIIB-Specific Antibodies and Methods of Use Thereof. U.S. Patent Application No. US20190218288A1, 18 July 2019.

99. Arce Vargas, F.; Furness, A.J.S.; Litchfield, K.; Joshi, K.; Rosenthal, R.; Ghorani, E.; Solomon, I.; Lesko, M.H.; Ruef, N.; Roddie, C.; et al. Fc Effector Function Contributes to the Activity of Human Anti-CTLA-4 Antibodies. Cancer Cell 2018, 33, 649-663 e644. [CrossRef]

100. Arlauckas, S.P.; Garris, C.S.; Kohler, R.H.; Kitaoka, M.; Cuccarese, M.F.; Yang, K.S.; Miller, M.A.; Carlson, J.C.; Freeman, G.J.; Anthony, R.M.; et al. In vivo imaging reveals a tumor-associated macrophage-mediated resistance pathway in anti-PD-1 therapy. Sci. Transl. Med. 2017, 9. [CrossRef]

101. Dahan, R.; Sega, E.; Engelhardt, J.; Selby, M.; Korman, A.J.; Ravetch, J.V. FcgammaRs Modulate the Anti-tumor Activity of Antibodies Targeting the PD-1/PD-L1 Axis. Cancer Cell 2015, 28, 285-295. [CrossRef] [PubMed]

102. Hogarth, P.M.; Pietersz, G.A. Fc receptor-targeted therapies for the treatment of inflammation, cancer and beyond. Nat. Rev. Drug Discov. 2012, 11,311-331. [CrossRef]

103. Engblom, C.; Pfirschke, C.; Pittet, M.J. The role of myeloid cells in cancer therapies. Nat. Rev. Cancer 2016, 16, 447-462. [CrossRef] [PubMed]

104. Guilliams, M.; Bruhns, P.; Saeys, Y.; Hammad, H.; Lambrecht, B.N. The function of Fcgamma receptors in dendritic cells and macrophages. Nat. Rev. Immunol. 2014, 14, 94-108. [CrossRef] [PubMed]

105. Rankin, C.T.; Veri, M.C.; Gorlatov, S.; Tuaillon, N.; Burke, S.; Huang, L.; Inzunza, H.D.; Li, H.; Thomas, S.; Johnson, S.; et al. CD32B, the human inhibitory Fc-gamma receptor IIB, as a target for monoclonal antibody therapy of B-cell lymphoma. Blood 2006, 108, 2384-2391. [CrossRef]

106. Jung, S.T.; Reddy, S.T.; Kang, T.H.; Borrok, M.J.; Sandlie, I.; Tucker, P.W.; Georgiou, G. Aglycosylated IgG variants expressed in bacteria that selectively bind FcgammaRI potentiate tumor cell killing by monocyte-dendritic cells. Proc. Natl. Acad. Sci. USA 2010, 107, 604-609. [CrossRef] [PubMed]

107. White, A.L.; Chan, H.T.; Roghanian, A.; French, R.R.; Mockridge, C.I.; Tutt, A.L.; Dixon, S.V.; Ajona, D.; Verbeek, J.S.; Al-Shamkhani, A.; et al. Interaction with FcgammaRIIB is critical for the agonistic activity of anti-CD40 monoclonal antibody. J. Immunol. 2011, 187, 1754-1763. [CrossRef] [PubMed]

108. Li, F.; Ravetch, J.V. Inhibitory Fcgamma receptor engagement drives adjuvant and anti-tumor activities of agonistic CD40 antibodies. Science 2011, 333, 1030-1034. [CrossRef]

109. White, A.L.; Chan, H.T.; French, R.R.; Beers, S.A.; Cragg, M.S.; Johnson, P.W.; Glennie, M.J. FcgammaRIotaIotaB controls the potency of agonistic anti-TNFR mAbs. Cancer Immunol. Immunother. 2013, 62, 941-948. [CrossRef]

110. Beutier, H.; Hechler, B.; Godon, O.; Wang, Y.; Gillis, C.M.; de Chaisemartin, L.; Gouel-Cheron, A.; Magnenat, S.; Macdonald, L.E.; Murphy, A.J.; et al. Platelets expressing IgG receptor FcgammaRIIA/CD32A determine the severity of experimental anaphylaxis. Sci. Immunol. 2018, 3. [CrossRef] 
111. Smith, P.; DiLillo, D.J.; Bournazos, S.; Li, F.; Ravetch, J.V. Mouse model recapitulating human Fcgamma receptor structural and functional diversity. Proc. Natl. Acad.Sci. USA 2012, 109, 6181-6186. [CrossRef]

112. Lee, C.H.; Kang, T.H.; Godon, O.; Watanabe, M.; Delidakis, G.; Gillis, C.M.; Sterlin, D.; Hardy, D.; Cogne, M.; Macdonald, L.E.; et al. An engineered human Fc domain that behaves like a pH-toggle switch for ultra-long circulation persistence. Nat. Commun. 2019, 10, 5031. [CrossRef]

(C) 2020 by the authors. Licensee MDPI, Basel, Switzerland. This article is an open access article distributed under the terms and conditions of the Creative Commons Attribution (CC BY) license (http://creativecommons.org/licenses/by/4.0/). 